\title{
Sağlık Çalışanlarının Değişime Karşı Tutumlarının İncelenmesi (Investigation of Health Worker's Attitudes to Change)
}

\section{Fuat KORKMAZER iD a Tülay ASLAN ${ }^{\text {iD }}$ b Erhan EKINGEN (iD c}

a Muş Alparslan Üniversitesi, Sağlık Bilimleri Fakültesi, Sağlık Yönetimi Bölümü, Muş, Türkiye. f.korkmazer@alparslan.edu.tr

b Frrat Üniversitesi, Sosyal Bilimler Enstitüsü, Sağlık Yönetimi Bilim Dalı, Elazığ, Türkiye. tulin.aslan21@gmail.com

c Batman Üniversitesi, Sağlık Yüksekokulu, Sağlık Yönetimi Bölümü, Batman, Türkiye. erhan.ekingen@batman.edu.tr

\begin{tabular}{|c|c|}
\hline MAKALE BİLGİSİ & ÖZET \\
\hline $\begin{array}{l}\text { Değişim } \\
\text { Değişim Yönetimi } \\
\text { Sağlık Çalışanları }\end{array}$ & $\begin{array}{l}\text { Amaç - Toplumun sağlık düzeyinin yükseltilmesi, koruyucu sağlık hizmetlerinin yerinde } \\
\text { uygulanması, kaliteli bir sağlı politikası ve yaşam koşullarının iyileştirilmesi ile mümkündür. Bu } \\
\text { hizmetlerin yerine getirilmesinde sağlık yöneticilerine çok önemli roller düşmektedir. Bu çalışmanın } \\
\text { amaç sağlık çalışanlarının sağlıkta gerçekleşen değişimi nasıl değerlendirdiklerini belirlemek ve } \\
\text { değişime karşı tutumlarını ölçmektir. }\end{array}$ \\
\hline $\begin{array}{l}\text { Gönderilme Tarihi } 1 \text { Haziran } \\
2020 \\
\text { Revizyon Tarihi } 14 \text { Temmuz } \\
2020 \\
\text { Kabul Tarihi } 13 \text { Ağustos } 2020\end{array}$ & $\begin{array}{l}\text { Yöntem - Araştırma kapsamında Elazı̆̆ ilinde faaliyet gösteren Özel Medikal Park Hastanesi ve } \\
\text { Elazığ Devlet Hastanesinde çalışan } 276 \text { sağlık çalışanına ulaşılmıştır. Araştırmada Seren (2005) } \\
\text { tarafından geliştirilen } 29 \text { maddelik Değişime Karşı Tutum Ölçeği ve bilgi formundan } \\
\text { yararlanılmıştır. Çalışmadan elde edilen veriler SPSS } 21 \text { istatistik programı ile analiz edilmiştir. } \\
\text { Bulgular - Elde edilen bulgulara göre sağlık çalışanlarının kişisel bilgilerinin değişime dair tutum } \\
\text { geliştirmede farklı etkilerinin bulunduğu ve DKTÖ en düşük puan ortalamasının kamu } \\
\text { hastanesinde olduğu tespit edilmiştir. } \\
\text { Tartışma - Bu çalışma sonucunda sağlık çalışanlarının değişime karşı kaygılarının azaltılması } \\
\text { yönünde çalışmaların yapılması önerilmektedir. }\end{array}$ \\
\hline ARTICLE INFO & ABSTRACT \\
\hline $\begin{array}{l}\text { Keywords: } \\
\text { Change } \\
\text { Change Management } \\
\text { Health Workers }\end{array}$ & $\begin{array}{l}\text { Purpose - Raising the level of public health is possible by implementing preventive health services } \\
\text { in place, by improving quality health policy and living conditions. The fulfillment of these services } \\
\text { has a crucial role for health care providers. The aim of this study is to determine how health workers } \\
\text { perceive the change in health and to measure their attitudes towards change. }\end{array}$ \\
\hline $\begin{array}{l}\text { Received } 1 \text { June } 2020 \\
\text { Revised } 14 \text { July } 2020 \\
\text { Accepted } 13 \text { August } 2020\end{array}$ & $\begin{array}{l}\text { Design/methodology/approach - Within the scope of the research, } 276 \text { health workers working in } \\
\text { Private Medical Park Hospital and Elazığ State Hospital operating in Elazığ province were reached. } \\
\text { The } 29 \text {-item Variation Attitude Scale and information form developed by Seren (2005) were used in } \\
\text { the research. Data obtained without study were analyzed by SPSS } 21 \text { statistical program. }\end{array}$ \\
\hline $\begin{array}{l}\text { Article Classification: } \\
\text { Research Article }\end{array}$ & $\begin{array}{l}\text { Findings - According to the findings, it was determined that the personal information of the health } \\
\text { workers had different effects on improving the attitude towards change and the lowest average score } \\
\text { of the DKTÖ was found in the public hospital. } \\
\text { Discussion - As a result of this study, it is suggested that health workers should try to reduce their } \\
\text { concerns about change. }\end{array}$ \\
\hline
\end{tabular}

\section{Giriş}

Değişim genel anlamı ile "herhangi bir şeyde belirli bir sürede oluşan farklılaşma" şeklinde tanımlanmaktadır. Başka bir tanımla değişim, bir bütünün parçaları, parçaların ilişkileri, önceki duruma göre nicel ve nitel şekilde gözlemlenebilen bir farklılı̆̆ın oluşmasına denir (Özmen ve Sönmez 2007: 178).

Teknoloji, sosyal, ekonomi ve siyasi yapıların sürekli şekilde değişmesi işletmeler üzerinde çevreye uyum amacıyla değişim yönünde bir baskı oluşturmakta, sistemin yapı ve işleyişinde de gerekli değişiklikleri yapmaya zorlamaktadır. Günümüz işletmeleri varlığını sürdürebilmek ve faaliyet gösterdikleri pazarda rekabet edebilmek için çevrelerinde yaşanan değişim sürecine uyum sağlamak durumundadır. Yaşanan bu baskı ve zorunluluk, işletmelerin işleyişinde önemli bazı değişim ve gelişmeler meydana getirmektedir.

\section{Önerilen Atıf/Suggested Citation}

Korkmazer, F., Aslan, T., Ekingen, E. (2020). Sağlık Çalışanlarının Değişime Karşı Tutumlarının İncelenmesi, İşletme Araştırmaları Dergisi, $12(3), 2580-2591$. 


\section{F. Korkmazer - T. Aslan - E. Ekingen 12/3 (2020) 2580-2591}

Günümüzün en temel itici gücü olan değişim artık bir varlık-yokluk sorunu haline gelmiştir. Günümüzde yaşanan değişim, geleneksel çizginin dışında, farklı durumlarda farklı düşünce tarzlarının geliştirilmesi ihtiyacını ortaya koymuştur. Bu temel değişiklik, değişime "hızlı, yoğun ve etkin" müdahaleyi zorunlu kılmıştır (Yeniçeri, 2002: 9).

Günümüzde insanlar zamanlarının çoğunu çalıştıkları kurumlarda geçirmektedirler. Çalışan insanlar hizmet verdikleri kurumlarda yaşanan değişimlere ayak uydurmak zorundadırlar. 21. yüzyıl işletmeler için değişimin alansal olarak arttığı ve rekabet edebilirlik açısından değişime hızlı ve etkin uyum sağlamanın öneminin arttığı bir yüzyılı temsil etmektedir (Akgeyik, 2001: 120). Günümüzde, değişimin gerekli olmasından ziyade değişim ve dönüşümün sürekliliğinin nasıl sağlanacağı önem kazanmıştır. Günümüzde, küreselleşme nedeniyle oluşan hızlı rekabet ortamında kabul gören diğer bir gerçek te, değişimin ve gelişimin yönetimini kavrayamamış, stratejilerini yenilememiş ve hatta bu durumu tehdit olarak algılamış olan işletmelerin ayakta kalma şanslarının olmadığıdır (Ünal, 2012: 22).

Sağlık hizmetleri, toplumda yaşayan kişileri çeşitli sakatlık ve hastalıklardan koruyarak, psikolojik, ekonomik ve toplumsal açıdan hayatlarını huzur içerisinde idame ettirebilmelerini amaçlayan faaliyetler bütünüdür (Akdur, 2006: 17-20). Sağlık hizmetlerinin hayati özelliği, hizmetlerin üretiminde çalışanların oynadığı ciddi rol ile sahip olduğu özellikler sağlık çalışanlarının önemini arttırmış ve etki alanlarının gelişmesine yol açmıştır (Kavuncubaşı ve Yıldırım, 2015: 343). Sağlığı elde etmek, korumak, güçlendirmek ve devamlılığını sağlanmak amacıyla, ürün ve hizmet üreten tüm kurum ve kuruluşlardan oluşan yapı da sağlık sektörünü oluşturmaktadır (Akın, 2007: 6). Sağlık personeli, insan sağlığının korunup ve geliştirilmesi, hastalıkların teşhis ve tedavi edilmesi, ruhsal, bedensel ve sosyal açıdan tam bir iyilik halinin oluşturulması ve devamının sağlanması amacıyla çalışan kişilerdir (www.turkadlitip.com).

21. yüzyıldaki değişimlerin öncülük ettiği kurumlardan biri de sağlık kurumlarıdır. Ülkemizde sağlık sisteminde yaşanan değişim ve sağlıkta dönüşüm programı süreciyle beraber sağllk hizmetlerinin sunumunda önemli gelişmeler yaşanmıştır. Sağlik Bakanlığının sağlikta dönüşüm programının sağlik çalışanlarına etkilerini ölçmek için yaptırdığı sağlık çalışanları memnuniyeti araştırmasına göre; performansa dayalı ek ödeme, izin kullanma sırasında ek ödemenin kesilmesi, meslekler arasında ek ödemede büyük farklılıkların olması, ek ödemelerin geleceği ile ilgili belirsizlik gibi memnuniyetsizlik nedenleri belirlenmiştir (Sağlık Bakanlığı, 2009: 100-150). Yaşanan bu gelişmeler doğrultusunda aynı zamanda bu hizmetleri sunan sağlık çalışanlarının başarılı ve üretken olabilmeleri için, sağlık kurumlarında yaşanan değişime karşı göstermiş oldukları bağlılık önem arz etmektedir.

\section{Örgütsel Değisşim}

Değişim ihtiyacı işletmelerin kendi iç dinamiklerinden oluştuğu gibi işletme dışındaki faktörlerin etkisiyle de oluşabilmektedir. İşgücünün değişen yapısı ile özellikle nitelikli işgücü oranında yaşanan artış, işgücü piyasalarını bu değişimlere uyum sağlamaya zorlamaktadır. Sanayi toplumundaki standart istihdam şekilleri, yerini bilgi toplumunda standart dışı istihdam şekillerine bırakmaktadır. Teknolojide yaşanan hızlı değişim, arz-talepteki değişiklikler ve konjoktürel dalgalanmaların sıradanlaştığı bir durumda işletmeler tarafından değişime uyum sağlama, dahası değişimi yönlendirmenin önemi kavranmıştır (Düzel Dilden, 2010: 7).

Örgütsel değişimdeki amaç, çevredeki değişimlere uyum sağlamak ve bunun sonucunda rekabetin yoğun ortamına uyum sağlamaktır. Buradaki en önemli faktör, işletmedeki insan faktörüdür. Bilgi, yetenek ve davranış olarak çalışanlarını çağın gereklerine uyumlaştırmadan, sadece teknolojik araçları, süreçleri ve yapılarında değişiklik yapan işletmeler uzun dönemli başarılar elde edemeyecektir. Bu bağlamda işletmelerin rekabetin yoğun olduğu ortamda, yetkinlikleri arttırılan ve işletme amaçlarına inanan insan kaynağını oluşturmak temel bir zorunluluktur (Düzel Dilden, 2010: 8).

İşletmeleri değişime zorlayan nedenleri başlık altında incelemek mümkündür. Bu nedenler örgüt içi ve örgüt dışı şeklindedir (Dursun, 2007: 40-41). İçsel nedenler: organizasyon yapısındaki bazı gelişme, durum ve olaylara dairdir. Örneğin verimliliğin düşük olması, kalite açısında düşüş, moral düzeyi düşüklüğü, kişi ya da gruplar arasındaki çatışmaların yoğunluğu, çalışan beklentilerindeki artış gibi unsurlar, işletme içerisinde çeşitli konularda değişiklik yapılmasını gerekli kılmaktadır. Dışsal nedenler: rekabet, kültür ve kültürel değerlerdeki değişim, teknolojide yaşanan değişim, bilimsel alanda yaşanan değişim, ihtiyaçların artması, 


\section{F. Korkmazer - T. Aslan - E. Ekingen 12/3 (2020) 2580-2591}

kaynakların kullanım biçiminde oluşan değişimler, işletme sahiplerinin amaçlarındaki değişimler olarak siralanmaktadır (Seren, 2005: 43-44).

\section{Değişim Yönetimi}

Değişim, değişim sürecini yönetme, değişime karşı dirençlerle başa çıkma gibi konular yönetimde temel sorunları oluşturmuştur. İşletmelerin yaşamlarını sürdürebilmeleri için değişimi yaşamak ve değişimi işletme vizyonu haline getirerek sürekli kılmak gerekmektedir (Koçel, 2010: 28). Çevre şartlarının kaçınılmaz kıldığ1 değişim, yeniden örgütlenme, yeni çalışma yöntemlerine uyum sağlama kısacası değişimi yönetmeyi kaçınılmaz hale getirmektedir (White, 2000: 162). Bazı işletmeler değişimin süreçlerini içerisinde bulundukları toplumdan daha çabuk gerçekleştirirken, bazıları ise bu değişimi daha yavaş gerçekleştirmektedir. Bununla birlikte, faaliyet sürdürdükleri toplumum değişim hızından daha az değişen işletmelerin varlıklarını sürdürmesi olası değildir. Bunun için, özellikle işletmede karar verme merciindeki yöneticilerin toplumda yaşanan değişimleri izleyerek, işletmelerindeki değişimi yönetmeleri oldukça önem arz etmektedir (Jones, 1998: 15).

Değişimi kişisel düzeyde ve örgütsel düzeyde ele almak mümkündür. Kişisel düzeyde değişim işletmelerde değişimin ana unsurudur. Bu sebeple her işletmede çalışanı yaratıcı kılma yönünde farklı önlemler alınarak bu konuda farklı öneriler geliştirilmektedir. Kişisel düzeydeki değişim; çalışanla işletme arasındaki biçimsel, psikolojik ve sosyal ilişkilere etki etmektedir. Biçimsel yön, çalışanın işletmede yaptığı iş ile ilgili kendisiyle işletme arasında; psikolojik yön, çalışanın işletmeye bağlılığını oluşturan; sosyal yön ise çalışan ile işletmenin kişisel kültür yapısı ve değer yargıları arasındaki ilişkileri açıklamaktadır (Siegal, 1998: 230-235). Örgütsel düzeyde değişim ise, değişen çevre koşullarından dolayı, işletmenin etkililiğini artırma, iş gereklerini yerine getirme, işletme çalışanları ve müşterilerinin beklentilerine cevap verme maksadıyla işletmenin tümünde etkileşim göz önüne alınarak değişiklikler yapılmasıdır. İşletmelerin faaliyet gösterdikleri çevrenin sürekli değişmesi, çevrede oluşan tepkiler doğrultusunda varlığını sürdürmesi, yapı ve amaçlarını yeniden düzenleyerek yeni bir oluşum içerisine girmelerini gerektirmektedir (Tokat, 2012: 24).

Değişimi başarıyla gerçekleştirmek için, vizyonu belirginleştirilme ve paylaşımını sağlama, değişimin gerçekleşmesi için gereken faaliyetleri ayrıntılı olarak belirleme, işlerin yapılması için gereken sorumluluğu dağıtma, işleri öncelik durumuna göre sıralama, planları hayata geçirebilmek için gerekli bütçeyi hazırlama, uygulama ekipleri ve yapıları oluşturma, işleri liyakat esasına göre dağıtma, gerektiğinde personel takviyesi yapma, uygulamayı gerçekleştirmek için gerekli prosedürleri oluşturmak gereklidir (Altındiş, Altındiş ve Sayl1, 2011: 91).

\section{Yöntem}

Çalışma, sağlıkta dönüşüm programıla beraber yaşanan değişimlere karşı çalışanların görüş, tutum ve davranışlarını değerlendirmeye yönelik literatür taramasından oluşan ilk bölüm ile birlikte, Elazığ ilinde faaliyet gösteren bir özel ve bir de kamuya ait iki sağlık kurumundaki uygulamadan oluşmaktadır. Çalışma 2017 yılında Mayıs-Haziran ayları arasında yapılmıştır. Saha çalışması ile ilgili gerekli izinleri almak için yapılan görüşmelerde kurum yetkililerinin yönlendirme ve talepleri doğrultusunda, anket formlarının ilgili kurumun görevlendirdiği personel nezaretinde yürütülmesine karar verilmiştir.

Çalışmadan elde edilen veriler SPSS.21 istatistik programı ile analize tabi tutulmuştur. Çalışmadan elde edilen veriler normal dağılım göstermediği için parametrik olmayan testler (Kolmogorof Simirnov, Mann-Whitney U testi ve Kruskall Wallis) kullanılmıştır. Güvenirlik analizi kullanılarak Crombach Alfa katsayısı tespit edilmiştir. Veriler tablolarda aritmetik ortalama $( \pm)$, standart sapma, katılımcı sayı ve yüzdesi şeklinde belirtilerek güven aralığ $\% 90$ olarak alınmıştır.

Araştırmanın temel hipotezi; Sağlık çalışanlarının değişime yönelik dirençlerinin olduğu ve bu direnç algısının sosyo demografik özelliklere göre farklılık oluşturduğudur.

\section{Araştırmanın Amacı}

Araştırmanın amacı sağlık çalışanlarının sağlık sektöründe Sağlıkta Dönüşüm Programıyla beraber yaşanan değişimlere karşı görüşlerini, tutumlarını ve davranışlarını değerlendirmektir. Ayrıca çalışma, sağlıkta dönüşüm programı uygulamalarının yöneticiler ve yönetici olmayan sağlık çalışanlarınca değerlendirilerek bu programa karşı direncin olup olmadığını tespit etmeyi amaçlamıştır. Bu temel amaç doğrultusunda 


\section{F. Korkmazer - T. Aslan - E. Ekingen 12/3 (2020) 2580-2591}

demografik bilgiler ile değişime karşı tutum ölçeği boyutları arasındaki ilişkilerin belirlenmesi de amaçlanmıştır.

Bu araştırmadan elde edilecek sonuçlarla sağlık personelinin mevcut değişimlere karşı tutumlarını izleme ve gelecekte yapılacak olan yeni çalışma sonuçlarıyla literatürde yer alan araştırmalarla karşılaştırma yapmak amaçlanmaktadır. Ayrıca Sağlık Bakanlığı tarafından geliştirilecek yeni sağlık reformlarında sağlık çalışanlarının bu reformlara karşı gösterecekleri tutumların incelenmesinde faydalanılması gibi nihai hedeflere ulaşılması amaçlanmaktadır.

\section{Araştırmanın Evren ve Örneklemi}

Araştırma evrenini, Elâzı̆̆g'da faaliyet gösteren Özel Medikal Park Hastanesi ve Elazı̆̆ Eğitim ve Araştırma Hastanesi çalışanı olan 1265 sağlık personeli oluşturmaktadır. Evren kapsamındaki tüm sağlık çalışanlarına ulaşılarak anketin uygulanması arzu edilmiştir. Ancak izin, görevlendirme ve anketin doldurulmak istenmemesi gibi nedenlerle sağlık çalışanlarına 450 anket dağıtılabilmiştir. Dağıtılan anketlerden 287'si geri dönmüştür. Dağıtılan anketlerden geri dönen anket formları incelenmiş, hatalı ya da eksik doldurulan formların değerlendirmeye dâhil edilmemesi sonucu 276 anket formu analiz kapsamına alınmıştır. Örneklem sayısı (276), araştırma evreninin \% 21,82'sini oluşturmaktadır.

\section{Veri Toplama Araçları}

Verileri toplamada Kişisel Bilgiler Formu ile Değişime Karşı Tutum Ölçeğinden (DKTÖ) yararlanılmıştır.

Kişisel Bilgiler Formu: Katılımcıların kişisel bilgilerini ölçmeye yönelik bu form, çalışanların yaş, cinsiyet, medeni durum, eğitim durumu, çalışma süresi, unvan, idari görevin olup olmaması ve çalışılan kurumun kamu veya özel sektörde olma durumuna ilişkin sekiz sorudan oluşmaktadır.

Değişime Karşı Tutum Ölçeği: Seren (2005)'in geliştirdiği çalışanların değişime karşı tutumunu ölçmeyi amaçlayan 29 ifadeden oluşmaktadır. Likert tipinde hazırlanan ölçekteki tüm maddeler "kesinlikle katılmıyorum", "katılmıyorum", "kararsızım", "katılıyorum", "kesinlikle katılıyorum" olarak 1-5 puan aralığında sıralanmıştır. DKTÖ' den alınabilecek en düşük puan 29, en yüksek puan da $145^{\prime}$ tir. Ölçekten elde edilen puan toplamı değişime yönelik algının düzeyini belirlemektedir. Ölçekten elde edilen puan toplamının yükselişi değişime yönelik algıda pozitif yönde artış olduğunu göstermektedir. Seren (2005) ölçeğin Cronbach Alfa değerini 0,910 olarak bulmuş, bu çalışmada da ölçeğin Cronbach Alfa değeri 0,916 olarak tespit edilmiştir. Bu bağlamda ölçeğin güvenilirliğinin yüksek derecede olduğu tespit edilmiştir.

\section{Bulgular}

Tablo 1. Ölçeğin Faktör ve Güvenilirlik Analizi
Boyutlar
Faktör Yükleri
Cronbach Alpha

\begin{tabular}{ll}
\hline Değişimde Kurumsal Politika & \multicolumn{1}{c}{, $\mathbf{8 8 8}$} \\
\hline D8 & 757 \\
\hline D7 &, 748 \\
\hline D9 &, 744 \\
\hline D5 &, 657 \\
\hline D4 &, 654 \\
\hline D10 &, 611 \\
\hline D1 &, 608 \\
\hline D2 &, 605 \\
\hline D11 &, 587 \\
\hline D12 &, 552 \\
\hline D3 &, 541 \\
\hline D6 &, 496 \\
\hline
\end{tabular}


F. Korkmazer - T. Aslan - E. Ekingen 12/3 (2020) 2580-2591

\begin{tabular}{lll}
\hline Değişimin Sonuçları & \multicolumn{1}{c}{, $\mathbf{8 1 2}$} \\
\hline D16 &, 684 & \\
\hline D17 &, 653 & \\
\hline D29 &, 593 &, 637 \\
\hline D20 &, 592 & \\
\hline D28 &, 576 & \\
\hline D27 &, 443 & \\
\hline D25 &, 388 &, 507 \\
\hline D26 &, 579 & \\
\hline Değişime Direnç &, 745 & \\
\hline D15 &, 682 & \\
\hline D22 &, 606 & \\
\hline D23 &, 506 & \\
\hline D21 & & \\
\hline D13 &, 570 & \\
\hline Değişimi Yönetim Tarzi &, 567 & \\
\hline D19 &, 505 & \\
\hline D18 &, 496 & \\
\hline D24 & & \\
\hline D14 & & \\
\hline
\end{tabular}

Tablo 2.2 incelendiğinde; Değişime Karşı Tutum Ölçeğinin alt boyutlarının Cronbach Alpha katsayısı 0,507 ile 0,888 arasında değiştiği Değişime Karşı Tutum Ölçeğinin genel Cronbach Alpha katsayısı ise 0,916 olarak hesaplanmıştır. Yapılan faktör analizi sonucunda, Değişime Karşı Tutum Ölçeğinin öngörüldüğü gibi 4 faktörle açıklandığı görülmüştür. Kullanılan ölçeklere ilişkin Cronbach Alfa katsayılarına bakıldığında, Cronbach Alfa değeri 0,80 - 1,00 aralığında olduğu için ölçeğin yüksek düzeyde güvenilir olduğu söylenebilir (Büyüköztürk, 2006: 171; Kalayc1, 2008: 405).

Tablo 2. Sosyo - Demografik Özelliklere Yönelik Bulgular

\begin{tabular}{llll}
\hline Sosyo-Demografik Bilgiler & & $\mathbf{n}$ & $\mathbf{\%}$ \\
\hline \multirow{4}{*}{ Yaş } & $18-25$ & 36 & 13,0 \\
\cline { 2 - 4 } & $26-30$ & 64 & 23,2 \\
\cline { 2 - 4 } & $31-35$ & 48 & 17,4 \\
\cline { 2 - 4 } & $36-40$ & 65 & 23,6 \\
\cline { 2 - 4 } Cinsiyet & 41 ve üstü & 63 & 22,8 \\
\hline \multirow{2}{*}{ Medeni Durum } & Kadın & 136 & 49,3 \\
\cline { 2 - 4 } & Erkek & 140 & 50,7 \\
\hline \multirow{3}{*}{ Eğitim Durumu } & Evli & 725 & 54,7 \\
\cline { 2 - 4 } & Bekâr & 72 & 25,3 \\
\hline Unvan Durumu & Lise & 58 & 21,0 \\
\cline { 2 - 4 } & Ön lisans & 76 & 27,5 \\
\cline { 2 - 4 } & Lisans & 77 & 27,9 \\
\cline { 2 - 4 } & Lisansüstü & & \\
\hline
\end{tabular}


F. Korkmazer - T. Aslan - E. Ekingen 12/3 (2020) 2580-2591

\begin{tabular}{llcc}
\hline & Tabip Dışı Sağlık Personeli & 77 & 27,9 \\
\cline { 2 - 4 } & İdari Personel & 122 & 44,2 \\
\hline \multirow{3}{*}{ Çalışma Süresi } & 1 Yıldan Az & 14 & 5,1 \\
\cline { 2 - 4 } & $1-3$ Yıl & 70 & 25,4 \\
\cline { 2 - 4 } & $4-6$ Yıl & 80 & 29,0 \\
\cline { 2 - 4 } & $7-10$ Yıl & 42 & 15,2 \\
\cline { 2 - 4 } İdari Görev Durumu & 10 Y Ÿl Üzeri & 70 & 25,4 \\
\hline \multirow{2}{*}{ Çalıştığı Sektör } & Evet & 26 & 9,4 \\
\cline { 2 - 4 } & Hayır & 168 & 90,6 \\
\hline & Kamu & 108 & 39,9 \\
\cline { 2 - 4 } & Özel & $\mathbf{2 7 6}$ & $\mathbf{1 0 0}$ \\
\hline
\end{tabular}

Araştırmanın örnekleminin yaş itibariyle dağılımına bakıldığında, katılımcıların \%13'ü 18-25 yaş, \%23,2'si 2630 yaş, \% 17,4' ü 31-35 yaş, \%23,6 'sı 36-40 yaş, \% 22,8'i ise 41-üstü yaş aralığında yer almaktadır. Bu çerçevede örneklem ağırlıklı olarak (\%53,6’sı) 18-30 yaş aralığında bulunmaktadır. Tablo üzerinde de görüldüğü gibi örneklemin \%13'ü iş gücüne yeni katıldığı düşünülen 18-25 yaş aralığındaki genç çalışanlardan oluşmaktadır.

Araştırma örnekleminin cinsiyete göre dağılımına bakıldığında, katılımcıların \% 49,3'ünü kadın çalışanlar oluşturmakta, erkek katılımcıların da örneklemin geneli içindeki ağırlığının \% 50,7 seviyesinde olduğu görülmektedir.

Araştırma örneklemine medeni durum açısından bakıldığında, katılımcıların $\% 54,7^{\prime}$ sinin evli katılımcılardan, örneklemin \%45,3'ünün ise bekâr katılımcılardan oluştuğu görülmektedir.

Örnekleme dâhil edilen çalışanlar cinsiyete göre incelendiğinde, eğitim düzeylerinin oldukça yüksek olduğu görülmektedir. Bu verilere göre, örneklemin \% 21'inin üniversite, \% 26,1'inin meslek yüksekokulu, \% 25,4'ünün lise, \% 27,5'inin ise lisansüstü eğitime sahip olduğu görülmektedir. Zira örneklem dâhilindeki kurumların kaliteli hizmet sunmak için iş gücü özelikleri ile yetkinliklere önem vermesinin, çalışan seçimi ve istihdam süreçlerine insan kaynakları politikası çerçevesinde hareket ettiği görülmektedir. Bu çerçevede araştırma örnekleminin eğitim durumunun oldukça iyi bir seviyede olduğu görülmektedir.

Örnekleme meslekte çalışma süreleri açısından bakıldığında katılımcıların \% 5,1'i 1 yıldan az , \% 25,4'ü 1 ile 3 yıllık bir süredir çalışmakta, \% 29'u 4 ile 6 yıl arasında, \%15,2' si 7-10 yıl arasında,\% 25,4' ü ise 10 yıldan fazla çalışmakta olduğu görülmektedir. Söz konusu bulgular doğrultusunda, örneklem dâhilindeki kurum çalışanlarının kurumdaki kıdemlerinin yüksek olduğu söylenebilir.

Örnekleme unvan durumu açısından bakıldığında, Tabipler \% 27,9 Tabip dışındaki sağlık personeli \% 27,9’luk kısmı teşkil etmekte, idari personel ise \% 44,2'lik kısmı oluşturmaktadır. Bu bulgular doğrultusunda idari personelin çalışma koşulları müsait olduğu için çalışmaya katılımda daha hassas davrandığı söylenebilir.

Örnekleme idari görev durumu açısından bakıldığında, katılımcıların \% 9,4'ünün idari görevi olan çalışanlar oluşturmaktadır. Herhangi bir idari görevi bulunmayan çalışanların ise genel örneklem içindeki ağırlığı \% 90,6 seviyesinde olduğu görülmektedir.

Araştırma örneklemi çalıştığı sektör açısından incelendiğinde, katılımcıların \% 60,9'unu kamuda çalışan katılımcılar, özel sektörde çalışan katılımcıların ise örneklemin \% 39,1' ini oluşturduğu gözlenmiştir.

Tablo 3. Değişime Karşı Tutum Ölçeği (DKTÖ) Alt Boyut ve Toplam Puan Ortalaması 
F. Korkmazer - T. Aslan - E. Ekingen 12/3 (2020) 2580-2591

\begin{tabular}{lcccc}
\hline & Min & Max & Mean \pm SD & Range \\
\hline DKTÖ Alt Boyutları & & & & \\
\hline Değişimde Kurumsal Politika & 32,00 & 60,00 & $35,96 \pm 1,24$ & $12-60$ \\
\hline Değişimin Sonuçları & 23,00 & 40,00 & $23,79 \pm 1,17$ & $8-40$ \\
\hline Değişime Direnç & 11,00 & 25,00 & $14,04 \pm 1,14$ & $5-25$ \\
\hline Değişimi Yönetim Tarzı & 7,00 & 20,00 & $11,27 \pm 1,21$ & $4-20$ \\
\hline DKTÖ Toplam Puanları & 73,00 & 145,00 & $85,06 \pm 4,76$ & $29-145$ \\
\hline
\end{tabular}

Tablo 3'e bakıldığında Sağlık çalışanlarının değişime karşı tutum puan ortalaması 85,06 44,76'dır. Çalışanların

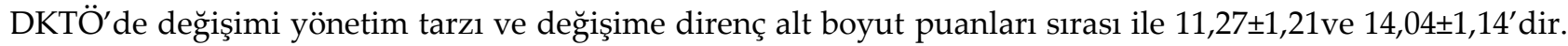
Çalışanların bu alt boyutlara ilişkin puanları diğer alt boyutlara nazaran daha düşüktür.

Tablo 4. Değişime Karşı Tutum Ölçeği (DKTÖ) Maddelerine Verilen Yanıtların Alt Boyutlara Göre Dağılımı

\begin{tabular}{|c|c|c|c|c|c|}
\hline İfadeler & $\begin{array}{c}\text { Kesin } \\
\text { Katılmiyorum }\end{array}$ & Katılmiyorum & Kararsızım & $\begin{array}{r}\text { Katıliyoru } \\
\text { m }\end{array}$ & $\begin{array}{r}\text { Kesin } \\
\text { Katılıyoru } \\
\text { m }\end{array}$ \\
\hline \multicolumn{6}{|l|}{ Değişimde Kurumsal Politika } \\
\hline $\begin{array}{l}\text { Kurumun değişim ihtiyacı yönetim } \\
\text { tarafından önceden belirlenir. }\end{array}$ & $83(30,1)$ & $49(17,8)$ & $36(13,0)$ & $91(33,0)$ & $17(6,2)$ \\
\hline $\begin{array}{l}\text { Kurum yöneticileri değişime önyargısız } \\
\text { yaklaşır. }\end{array}$ & $43(15,6)$ & $74(26,8)$ & $42(15,2)$ & $100(36,2)$ & $17(6,2)$ \\
\hline $\begin{array}{l}\text { Kurumda ulaşılmak istenen amaç ve } \\
\text { performans hedefleri yönetim tarafından } \\
\text { açıkça ifade edilir. }\end{array}$ & $23(8,3)$ & $49(17,8)$ & $49(17,8)$ & $145(52,5)$ & $10(3,6)$ \\
\hline $\begin{array}{l}\text { Kurumda değişim sonucunda, kaynaklar } \\
\text { daha etkin ve verimli kullanılır. }\end{array}$ & $25(9,1)$ & $82(29,7)$ & $56(20,3)$ & $88(31,9)$ & $25(9,1)$ \\
\hline $\begin{array}{l}\text { Kurumda değişim ile hasta ihtiyaçları daha } \\
\text { hızlı ve kaliteli karşılanır. }\end{array}$ & $10(3,6)$ & $83(30,1)$ & $64(23,2)$ & $91(33,0)$ & $28(10,1)$ \\
\hline $\begin{array}{l}\text { Kurumdaki değişimle beraber yönetim bilgi } \\
\text { teknolojisinden daha etkin yararlanmamı } \\
\text { sağlamaktadır. }\end{array}$ & $21(7,6)$ & $61(22,1)$ & $64(23,2)$ & $93(33,7)$ & $37(13,4)$ \\
\hline $\begin{array}{l}\text { Yöneticiler değişimin tüm aşamalarında biz } \\
\text { çalışanları yeterince destekler. }\end{array}$ & $39(14,1)$ & $54(19,6)$ & $97(35,1)$ & $71(25,7)$ & $15(5,4)$ \\
\hline $\begin{array}{l}\text { Yöneticiler değişim sırasında, diğer ekip } \\
\text { üyeleriyle işbirliğimi cesaretlendirir. }\end{array}$ & $61(22,1)$ & $67(24,3)$ & $56(20,3)$ & $68(24,6)$ & $24(8,7)$ \\
\hline $\begin{array}{l}\text { Yöneticiler, değişimin getirdiği tüm } \\
\text { yenilikleri benimsememiz için çaba harcar. }\end{array}$ & $54(19,6)$ & $64(23,2)$ & $47(17,0)$ & $84(30,4)$ & $27(9,8)$ \\
\hline $\begin{array}{l}\text { Bir üst yöneticim yeni uygulamalarda bana } \\
\text { model olur. }\end{array}$ & $47(17,0)$ & $66(23,9)$ & $59(21,4)$ & $79(28,6)$ & $25(9,1)$ \\
\hline $\begin{array}{l}\text { Kurumdaki değişim sürecinde ekip } \\
\text { üyeleriyle işbirliği içinde çalışırım. }\end{array}$ & $18(6,5)$ & $49(17,8)$ & $49(17,8)$ & $135(48,9)$ & $25(9,1)$ \\
\hline $\begin{array}{l}\text { Değişim, kurumun misyon ve vizyonuna } \\
\text { uygun olarak gerçekleşir. }\end{array}$ & $38(13,8)$ & $54(19,6)$ & $62(22,5)$ & $107(38,8)$ & $15(5,4)$ \\
\hline \multicolumn{6}{|l|}{ Değişimin Sonuçları } \\
\hline $\begin{array}{l}\text { Kurumdaki değişim, kişisel gelişimime } \\
\text { katkıda bulunur. }\end{array}$ & $60(21,7)$ & $56(20,3)$ & $54(19,6)$ & $94(34,1)$ & $12(4,3)$ \\
\hline $\begin{array}{l}\text { Değişim sürecinde kurumdaki değerler } \\
\text { korunur. }\end{array}$ & $37(13,4)$ & $68(24,6)$ & $65(23,6)$ & $87(31,5)$ & $19(6,9)$ \\
\hline $\begin{array}{l}\text { Değişim sürecinde elde edilen sonuçların } \\
\text { paylaşılması, değişimi kabulümü } \\
\text { kolaylaştırır. }\end{array}$ & $21(7,6)$ & $81(29,3)$ & $66(23,9)$ & $87(31,5)$ & $21(7,6)$ \\
\hline $\begin{array}{l}\text { Değişim sonrasında oluşturulan çalışma } \\
\text { grupları, değişimi sürekli kılar. }\end{array}$ & $34(12,3)$ & $84(30,4)$ & $66(23,9)$ & $78(28,3)$ & $14(5,1)$ \\
\hline
\end{tabular}


F. Korkmazer - T. Aslan - E. Ekingen 12/3 (2020) 2580-2591

\begin{tabular}{|c|c|c|c|c|c|}
\hline $\begin{array}{l}\text { Değişimin istenen sonuca ulaşmasında, ekip } \\
\text { üyesi olarak kendimi sorumlu hissederim. }\end{array}$ & $19(6,9)$ & $63(22,8)$ & $59(21,4)$ & $112(40,6)$ & $23(8,3)$ \\
\hline $\begin{array}{l}\text { Yaşadığım değişim süreciyle kuruma } \\
\text { bağlılığımı arttırır. }\end{array}$ & $36(13,0)$ & $64(23,2)$ & $67(24,3)$ & $85(30,8)$ & $24(8,7)$ \\
\hline $\begin{array}{l}\text { Kurumda yaşanan değişim sonucunda, } \\
\text { kurumun verimliliği artar. }\end{array}$ & $31(11,2)$ & $68(24,6)$ & $71(25,7)$ & $85(30,8)$ & $21(7,6)$ \\
\hline $\begin{array}{l}\text { Yaşanan değişim kuruma kalıcı bir başarı } \\
\text { sağlar. }\end{array}$ & $22(8,0)$ & $74(26,8)$ & $71(25,7)$ & $88(31,9)$ & $21(7,6)$ \\
\hline \multicolumn{6}{|l|}{ Değişime Direnç } \\
\hline $\begin{array}{l}\text { Kurumdaki değişim, ekip üyeleriyle } \\
\text { ilişkilerimi olumsuz etkilemektedir. }\end{array}$ & $33(12,0)$ & $107(38,8)$ & $53(19,2)$ & $65(23,6)$ & $18(6,5)$ \\
\hline $\begin{array}{l}\text { Kurumdaki değişim uygulamalarına tam } \\
\text { olarak katılırım. }\end{array}$ & $16(5,8)$ & $75(27,2)$ & $90(32,6)$ & $74(26,8)$ & $21(7,6)$ \\
\hline $\begin{array}{l}\text { Değişim sürecine katılımda çalışma isteğim } \\
\text { azalmaktadır. }\end{array}$ & $39(14,1)$ & $96(34,8)$ & $54(19,6)$ & $68(24,6)$ & $19(6,9)$ \\
\hline $\begin{array}{l}\text { Kurumdaki değişim sürecinde bazen işten } \\
\text { ayrılmayı düşünmekteyim. }\end{array}$ & $49(17,8)$ & $83(30,1)$ & $57(20,7)$ & $71(25,7)$ & $16(5,8)$ \\
\hline $\begin{array}{l}\text { Değişim sürecine katılımda çekimser } \\
\text { kalmaktayım. }\end{array}$ & $36(13,0)$ & $83(30,1)$ & $68(24,6)$ & $71(25,7$ & $18(6,5)$ \\
\hline \multicolumn{6}{|l|}{ Değişimi Yönetim Tarzı } \\
\hline $\begin{array}{l}\text { Kurumdaki değişim sırasında, kendi iş } \\
\text { alışkanlıklarımı sürdürmeme izin verilir. }\end{array}$ & $18(6,5)$ & $64(23,2)$ & $96(34,8)$ & $84(30,4)$ & $14(5,1)$ \\
\hline $\begin{array}{l}\text { Değişim ile ilgili istenen davranışı } \\
\text { gösterdiğimde ödüllendirilirim. }\end{array}$ & $55(19,9)$ & $79(28,6)$ & $53(19,2)$ & $72(26,1)$ & $17(6,2)$ \\
\hline $\begin{array}{l}\text { Değişim sürecinde yapılan ödüllendirmede } \\
\text { performansım dikkate alınır. }\end{array}$ & $53(19,2)$ & $73(26,4)$ & $62(22,5)$ & $72(26,1)$ & $16(5,8)$ \\
\hline $\begin{array}{l}\text { Yöneticiler değişim sürecinde zorlayıcı bir } \\
\text { yaklaşım sergiler. }\end{array}$ & $46(16,7)$ & $81(29,3)$ & $54(19,6)$ & $73(26,4)$ & $22(8,0)$ \\
\hline
\end{tabular}

Tablo 4' te katılımcıların Değişime Karşı Tutum Ölçeği (DKTÖ) sorularına verdikleri cevapların alt boyutlara göre dağılımı bulunmaktadır. Ölçeğin değişimde kurumsal politika alt boyutundaki yöneticilerin değişimin tüm aşamalarında çalışanları yeterince desteklediği ve kurumun ulaşmak istediği amaçların ve performans hedeflerinin yönetim tarafından açıkça ifade edildiğine yönelik maddelere en düşük oranda katılım sağlandığı tespit edilmiştir.

Bu çalışmada ölçeğin değişimin sonuçları alt boyutunda yer alan değişimin istenen sonuca ulaşmasında, ekibin bir üyesi olduğu için kendini sorumlu hissetme durumuna çalışanların \% 48,9'u katıllyorum ve tamamen katılıyorum yanıtı vermiştir. Sağlık çalışanları, ölçekte kurumdaki değişimle birlikte yönetimin bilgi teknolojilerinden daha etkin yararlanmasını sağladığı ve kurumun ulaşmak istediği amaç ve hedeflerin yönetim tarafından açık bir şekilde ifade edildiğine yönelik maddelere diğer maddelere nazaran daha yüksek oranda katılım sağlamışlardır.

Tablo 5. Değişime Karşı Tutumun Mann Whitney Testine Göre Dağılımı 
F. Korkmazer - T. Aslan - E. Ekingen 12/3 (2020) 2580-2591

\begin{tabular}{|c|c|c|c|c|}
\hline & $\mathbf{N}$ & $\begin{array}{c}\text { Sira } \\
\text { Ortalama }\end{array}$ & $\mathbf{W}$ & $\mathbf{P}$ \\
\hline \multicolumn{5}{|c|}{ Cinsiyet } \\
\hline Kadın & 136 & 146,01 & \multirow{2}{*}{18368,00} & \multirow{2}{*}{,123 } \\
\hline Erkek & 140 & 131,20 & & \\
\hline \multicolumn{5}{|c|}{ Medeni durum } \\
\hline Evli & 151 & 145,28 & \multirow{2}{*}{16288,50} & \multirow{2}{*}{,121 } \\
\hline Bekâr & 125 & 130,31 & & \\
\hline \multicolumn{5}{|c|}{ İdari görevi olma durumu } \\
\hline Evet & 26 & 162,15 & \multirow{2}{*}{34010,00} & \multirow{2}{*}{ 112 } \\
\hline Hayır & 250 & 136,04 & & \\
\hline \multicolumn{5}{|c|}{ Çalıştığı sektör } \\
\hline Kamu & 168 & 104,79 & \multirow{2}{*}{17604,50} & \multirow{2}{*}{, $000^{*}$} \\
\hline Özel & 108 & 190,94 & & \\
\hline
\end{tabular}

$(\mathrm{P}<0,05)$

Tablo 5.'e Katılımcıların, cinsiyet, medeni durum, idari görevin olması ve çalışılan sektör açısından bakıldığında:

Katılımcıların, cinsiyet, medeni durum, idari görevin olması grupları arasında değişime karşı tutum puanları açısından istatistiki olarak anlamlı bir farkın olmadığı görülmektedir. Katılımcıların, çalıştığı sektör grupları arasında değişime karşı tutum puanları açısından istatistiki olarak anlamlı bir farkın olduğu görülmektedir. Kamuda çalışanların puan sıralaması 104,79; özel sektörde çalışanların puan sıralaması ise 190,94'tür. Bu bulgulara göre; özel sektörde çalışanların değişime karşı tutum puanı sıralaması kamuda çalışanlara nazaran daha yüksektir.

Tablo 6. Değişime Karşı Tutumun Kruskal Wallis Testine Göre Dağılımı

\begin{tabular}{|c|c|c|c|c|}
\hline & $\mathbf{N}$ & Sira Ortalama & $X^{2}$ & $\mathbf{P}$ \\
\hline \multicolumn{5}{|l|}{ Yaş } \\
\hline $18-25$ & 36 & 157,24 & \multirow{5}{*}{15,188} & \multirow{5}{*}{, $004^{*}$} \\
\hline $26-30$ & 64 & 148,15 & & \\
\hline $31-35$ & 48 & 162,33 & & \\
\hline $36-40$ & 65 & 113,64 & & \\
\hline 41ve üstü & 63 & 125,48 & & \\
\hline \multicolumn{5}{|l|}{ Eğitim Durumu } \\
\hline Lise & 70 & 180,79 & \multirow{4}{*}{36,869} & \multirow{4}{*}{, $000^{*}$} \\
\hline Ön lisans & 72 & 130,42 & & \\
\hline Lisans & 58 & 145,50 & & \\
\hline Lisansüstü & 76 & 101,86 & & \\
\hline \multicolumn{5}{|l|}{ Unvan Durumu } \\
\hline Hekim & 77 & 107,31 & \multirow{3}{*}{17,144} & \multirow{3}{*}{, $000^{*}$} \\
\hline Hekim dışı sağlık personeli & 77 & 144,08 & & \\
\hline İdari personel & 122 & 154,66 & & \\
\hline \multicolumn{5}{|l|}{ Çalışma Süresi } \\
\hline 1 yıla kadar & 14 & 179,43 & \multirow{5}{*}{17,292} & \multirow{5}{*}{, $002^{*}$} \\
\hline $2-4$ yil & 70 & 155,42 & & \\
\hline $5-7$ y1l & 80 & 148,13 & & \\
\hline $8-10$ yil & 42 & 121,56 & & \\
\hline 10 yıl üstü & 70 & 112,55 & & \\
\hline
\end{tabular}




\section{F. Korkmazer - T. Aslan - E. Ekingen 12/3 (2020) 2580-2591}

Tablo 5.'e Katılımcların, farklı yaş, eğitim durumu, unvan ve çalışma süresi açısından bakıldığında:

Katılımcıların, yaş grupları arasında değişime karşı tutum puanları açısından istatistiki olarak anlamlı bir fark bulunduğu, 18-25 yaşındakilerin puan sıralamasının 157,24; 26-30 yaşındakilerin 148,15; 31-35 yaşındakilerin 162,33 ; 36-40 yaşındakilerin 113,64; 41 yaş ve üstündekilerin puan sıralamasının ise 125,48 olduğu görülmektedir. Bu bulgulara göre 36-40 yaşındakiler en düşük değişime karşı tutum puanı sıralamasına sahipken, 31-35 yaşındakiler en yüksek puan sıralamasına sahiptir.

Katılımcıların, öğrenim durumları arasında değişime karşı tutum puanları açısından istatistiki olarak anlamlı bir farkın bulunduğu, Lise mezunlarının puan sıralamasının 180,79; Ön lisans mezunlarının 130,42; Lisans mezunlarının 145,50; Lisansüstü mezunlarının puan sıralamasının ise 101,86 olduğu görülmektedir. Bu bulgulara göre lisansüstü mezunları en düşük değişime karşı tutum puanı sıralamasına sahipken lise mezunları en yüksek puan sıralamasına sahiptir.

Katılımcıların, unvanları arasında değişime karşı tutum puanları açısından istatistiki olarak anlamlı bir farkın bulunduğu, Tabiplerin puan sıralamasının 107,31; Tabip dışı sağlık personelinin 144,08; idari personelin puan sıralamasının ise 154,66 olduğu görülmektedir. Bu bulgulara göre tabiplerin değişime karşı tutum puanı sıralaması en düşük, idari personelin puan sıralaması ise en yüksektir.

Katılımcıların, meslekte çalışma süresi arasında değişime karşı tutum puanları açısından istatistiki olarak anlamlı bir farkın bulunduğu, 1 yıldan az çalışanların puan sıralamasının 179,43; 1-3 yıldır çalışanların 155,42; 4-6 yıldır çalışanların 148,13; 7-10 yıldır çalışanların 121,56; 10 yıldan fazla sürede çalışanların puan sıralamasının ise 112,55 olduğu görülmektedir. Bu bulgulara göre meslekte 10 yıldan fazla sürede çalışanlar en düşük değişime karşı tutum puanı sıralamasına sahipken 1 yıldan az çalışanlar en yüksek puan sıralamasına sahiptir. Başka bir deyişle; çalışanların çalışma süreleri arttıkça değişime karşı tutumlarında azalma görülmektedir.

\section{Sonuç ve Tartışma}

Sağlık hizmetleri ülkelerin ekonomik, sosyal, siyasi, kültürel ve entelektüel politikalarının temelini oluşturmaktadır. Bu hizmetleri sunanların başında sağlık çalışanları gelmektedir. İnsan sağlı̆̆ı gibi önemli ve hassas hizmet veren sağlık çalışanların sağlık kurumlarında yaşanan değişimlere karşı göstermiş oldukları tutum değerlendirilmiştir. Etkili bir sağlık hizmeti için insan kaynakları dediğimiz emek yoğun bir sektör olan sağlıkta, hizmetlerin verimli, kaliteli, erişilebilir ve zamanında sunulabilmesi için sağlık çalışanlarının iş doyumlarının ve motivasyonlarının yüksek, yöneticilerle ilişkilerinde başarılı olması ve yaşanan değişimlere ayak uydurmaları gerekmektedir.

Günümüzde yoğun bir şekilde yaşanan rekabet ve değişimden kaynaklanan stres, moral düşüklüğü ve çalışanlar arasındaki zayıf iletişim çalışanların verimliliğini düşürmektedir. Sağlık kurumlarında yaşanan olumlu değişimler, sağlık kurumlarının verimliliğini artırmaktadır. Çalışanlar bu değişimlere ayak uydurduklarında kurumun işçisi değil de kurumun bir parçası olduklarını düşünüp, kuruma karşı bir sorumluluk hissetmektedirler. Çalışanlara hizmet etmeyi hedef edinen hizmete yönelmiş yönetici davranışları çalışanları güdüleme, etkileme, teşvik etme ve güçlendirme olmalıdır. Bu teşvikler çalışanların kuruma olan sadakat, bağlılık ve inancını artırmaktadır. Bu da hem çalışanların etkin ve verimli olmaları konusunda hem de kurumun ulaşmak istediği hedefler doğrultusunda önemli bir adımdır.

Kamu ve Özel sektöre ait sağlık kurumlarında çalışan sağlık çalışanlarının değişime karşı tutum algısını belirlemeye yönelik yapılan bu çalışmada, sağlık çalışanlarının değişime karşı tutumunu yüksek düzeyde pozitif algıladığı belirlenmiştir. Ülkemizde sağlık kurumlarının yönetim yapısı ve anlayışı incelendiğinde, kamu ve özel hastanelerin farklı örgüt kültürleri olduğu ve bundan dolayı bu kurumlarda çalışan sağlık çalışanlarının da değişime karşı farklı tutumlarının olması beklenmektedir. Özel sağlık kuruluşlarında aşırı merkezi ve bürokratik bir yönetim yapısının olmaması, daha çok ekip çalışmasının benimsenmesi, hasta memnuniyeti ile birlikte çalışanların memnuniyetinin de önemsenmesi, çalışanların sürekli iletişim ve işbirliği içinde olmalarının işbirliği kültürünün görülmesinde etkisinin olduğu söylenebilir. Böyle bir organizasyon yapısı içerisinde çalışanların da yapılan değişimlere karşı olumlu tutum almaları beklenebilir. Kamuya bağlı sağlık kuruluşlarında ise; genellikle otokratik ve fazlasıyla bürokratik yönetim yapısı ve tarzı görülmesinde, güç kültürünün hâkim olmasının etkili olduğu söylenebilir. 


\section{F. Korkmazer - T. Aslan - E. Ekingen 12/3 (2020) 2580-2591}

Sağlık çalışanlarının değişime karşı tutum algısı üzerinde kişisel ve kurumsal bazı faktörlerin etkisi olabilmektedir. Bu çalışmada sağlık çalışanlarının çalıştığı sektör, farklı yaş, eğitim durumu, unvan ve çalışma süresi durumunun değişime karşı tutum algısı üzerinde etkisinin olduğu; ancak çalışanların cinsiyet, medeni durum ve idari görevi olma durumlarının etkisinin olmadığı tespit edilmiştir. Seren ve Baykal (2007)'ın yaptığ1 çalışmada kamu hastanelerinin değişime karşı tutum puanının özel hastanelere nazaran daha düşük olduğu ve istatistiki olarak yapılan karşılaştırmada ileri derecede anlamlı farkın bulunduğu tespit edilmiştir. Altındiş vd. (2011)' in yaptığı çalışmada hekimlerin değişimi en fazla destekleyen ve en az direnç gösteren grup olduğu, tıbbi sekreter, eczacı, diyetisyen ve fizyoterapistlerin ise diğer gruplara nazaran değişime daha fazla direnç gösterdiği tespit edilmiştir. Bostan ve Köse (2011)'nin yaptığı çalışmada ise yönetici görevi olanların değişimin uygulayıcısı olan güç tarafından atandıkları, yönetici görevi olmayanların ise değişime direncin aktörleri olduğu tespit edilmiştir.

Bu çalışmada sağlık çalışanlarının değişimi yönetim tarzı ve değişime direnç alt boyutuna yönelik değişime karşı tutum algısı diğer alt boyutlara nazaran daha düşük düzeyde olduğu tespit edilmiştir. Özellikle ölçeğin değişimde kurumsal politika alt boyutundaki çalışanlara kararlara katılımla ilgili fikirlerinin sorularak desteklendiği saygı duyulduğu ile ilgili maddelere sağlık çalışanlarının daha az oranda katıldıkları tespit edilmiştir. Sağlık çalışanlarının kendisini ekip içerisinde karar verme pozisyonda eksik ve yetkisiz görmesi, hekimlerin paternalistik ve geleneksel yaklaşımlarıyla açıklanabilir. Nitekim literatürde de hekimlerin sağlık sistemi içerisinde karar süreçlerinde kendilerini daha güçlü ve özerk olarak algıladıkları görülmektedir. 2006 yılında kamuda çalışan sağlık çalışanlarının Sağlıkta Dönüşüm Programı'nın uygulanmasıyla ilgili görüşlerinde; katılımcıların \% 86,2'si çalışma koşullarının ağırlaştığını, \% 81,1'i ise sağlık çalışanlarının toplumsal saygınlığının azaldığını belirtmişlerdir (Harmancı Seren, 2014: 19-24).

Sağlık kurumlarında yaşanan değişimler, etkin ve verimli hizmet sunumunda ve istenen performansın gösterilmesinde bazen sorunlar ortaya çıarmaktadır. Bunun için sağlık kurumları yöneticilerinin çalışanların bu değişimlere karşı tutumlarının nasıl olacağını, bilgi ve teknoloji alanındaki gelişmelerin ortaya çıkardığı zorunlu değişime uyumlarını sağlamak için çeşitli önlemler almalıdırlar. Bu önlemler kısaca:

- Çalışanların kurumun bir aile üyesi oldukları düşünülerek çalışanlara içten ve sıcak davranılmalıdır.

- Hata yapan çalışanın hatasını bir daha yapmaması için kendisi ile sıcak ilişkiler kurulmalı ve bu sıcaklığa inandırılmalıdır.

- Çalışanların kuruma olan bağlılıkları ve kurumsal amaçların başarılması için motivasyonlarını artırıcı çalışmalar yapılmalıdır.

- Çalışanların iş doyumunu artıracak uygun kurumsal iklim oluşturulmalıdır.

- Çalışanların tükenmişlik yaşamamaları için yaşadıkları sorunları çözmeye çalışılmalı, çalışanlarda olumlu katkıda bulunacak faaliyetler düzenlenmelidir.

- Çalışanların örgütsel değişim sürecine katılmalarının sağlanmasına yönelik örgüt iklimi oluşturulmalıdır.

- Çalışanların değişime yönelik hususlarda görüşleri alınmalı ve alınacak kararlara katkı sunmaları için kendilerine fırsatlar verilmelidir.

- Değişim sürecinde çalışanların paniğe kapılmaması için bilgilendirilmesi ve değişim sürecinin kendilerine iyi anlatılmalıdır.

- Değişime gösterilen direncin görünen nedenler dışındaki gizli nedenler tespit edilmeli ve ortadan kaldırılmalıdır.

- Kurumlarda oluşturulacak etkin iletişim sistemi kadar çalışanlara önemli olduklarını hissettirmeli, iş ve makam güvencesi verilmelidir. 


\section{Kaynakça}

Akdur, R. (2006). Sağllk Sektörü: Temel Kavramlar, Türkiye ve Avrupa Birliği'nde Durum ve Türkiye'nin Birliğe Uyumu. Ankara: A.Ü. Avrupa Toplulukları Araştırma ve Uygulama Merkezi Yayınları.

Akgeyik, T. (2001). Değişim Yönetimi: İnsan Kaynakları Yönetiminin Görev Alanı, İ.Ü. İktisat Fakültesi Maliye Araştırma Merkezi Yayınları, 40/1: 20.

Akın, C.S., (2007). Sağllk ve Sağlık Harcamalarının Ekonomik Büyüme Üzerine Etkisi: Türkiye'de Sağllk Sektörü Harcamaları, Çukurova Üniversitesi Sosyal Bilimler Enstitüsü, Yüksek Lisans Tezi, Adana.

Altındiş, M., Altındiş, S. ve Saylı, H., (2011). Sağlık Profesyonellerinin Değişim Karşısındaki Tutumlarını Belirlemeye Yönelik Bir Araştırma, ZKÜ Sosyal Bilimler Dergisi, 7/14: 75-93.

Bostan, S. ve Köse Ü. (2016) Sağlıkta Dönüşüm Programı Hakkında Yönetici ve Çalışan Görüşlerinin Karşılaştırılması Üzerinden Değiş̧ime Direncin Ölçülmesi, Verimlilik Dergisi, 3: 55-74.

Büyüköztürk, Ş. (2006) Sosyal Bilimler İçin Veri Analizi El Kitabı- İstatistik, Araştırma Deseni SPSS Uygulamaları ve Yorum, Ankara: Pegem Akademi Yayıncllı.

Dursun, E., (2007). Örgütsel Değiş̧im Karşısında Bireysel Direnç, Dumlupınar Üniversitesi Sosyal Bilimler Enstitüsü, Yüksek Lisans Tezi, Kütahya.

Düzel D., B., (2010). Değiş̧im Yönetimi, Bağlamında Ast Üst İlişkisi: Adana TEİAŞ Örneği, Gazi Üniversitesi Sosyal Bilimler Enstitüsü, Yüksek Lisans Tezi, Ankara.

Harmancı Seren, A.K., (2014). Sağlık Çalışanlarının Sağlıkta Dönüşüm Projesine İlişkin Görüşleri, Sağlık ve Hemşirelik Yönetimi Dergisi, 1/1: 19-24.

Jones, R., (1998), Organizational Theory, (USA: Prentice Hall).

Kalaycı, Ş. (2008). SPSS Uygulamalı Çok Değişkenli İstatistik Teknikleri. Ankara: Asil Yayın Dağıtım.

Kavuncubaşı, Ş. ve Yıldırım, S. (2015). Hastane ve Sağlık Kurumları Yönetimi, Ankara: Siyasal Kitapevi.

Koçel, T. (2010). İşletme Yöneticiliği, İstanbul: Beta Yayınevi.

Özmen, F. ve Sönmez, Y. (2007). Değişim Sürecinde Eğitim Örgütlerinde Değişim Ajanlarının Rolleri. Fırat Üniversitesi Sosyal Bilimler Dergisi, 17(2), 177-198.

Sağlık Bakanlığı. (2009). T. C. Sağlık Bakanlığı Personel Memnuniyet Araştırması, Ankara.

Seren, Ş. (2005). Değişime Karşı Tutum Ölçeğinin Geliştirilmesi ve Kalite Belgesi Alan Hastanelerde Değişim İle Örgüt Kültürü Arasındaki İlişkinin Değerlendirilmesi, İstanbul Üniversitesi Sağlık Bilimleri Enstitüsü, Doktora Tezi, İstanbul.

Seren Ş, ve Baykal Ü, (2007). Kalite Belgesi Alan Hastanelerde Örgüt Kültürü ve Değişime Karşı Tutumun İncelenmesi, Atatürk Üniversitesi Hemşirelik Yüksekokulu Dergisi, 10/2: 1-11.

Siegal, A., (1998). Understanding the Management of Change, Journal of Organizational Change Management, 9/2: 230-235.

Tokat, M.B. (2012). Örgütlerde Değişim ve Değiş̧im Yönetimi, İstanbul: Seçkin Yayıncllık.

Türk Adli Tip (2017), http://www.turkadlitip.com/saglik-personeli-kavrami-nedir/ (Erişim tarihi: 14 Temmuz 2017).

Ünal, M. (2012). 21.Yüzyılda Değişim, Yönetim ve Liderlik, İstanbul: Beta Yayınları.

White, L., (2000). Changing the Whole System in the Public Sector, Journal of Organizational Change Management, 13/2: 162-177.

Yeniçeri, Ö. (2002). Örgütsel Değişmenin Yönetimi, Ankara: Nobel Yayın Dağıtım. 